\title{
Identification of Sri Lankan Muroid Rodents using Hair Anatomy
}

\author{
D. M. C. Niroshini and Suyama Meegaskumbura* \\ Department of Zoology, Faculty of Science, University of Peradeniya, Sri Lanka. \\ Accepted November 26, 2014
}

\begin{abstract}
We report here characteristic features of hair anatomy of all fifteen muroid rodent species occurring in Sri Lanka. We examined cuticular scale patterns, cross-sections, medullae patterns, hair profile and made measurements (length and maximum width) of dorsal guard hairs. We also developed a dichotomous key for identification of rodent species based on hair anatomy, supported with photomicrographs of cuticular scales, medullae and illustrations of cross-sections. All species except spiny rats (Mus mayori and M. fernandoni) can reliably be distinguished from each other using hair anatomy, in most cases using a combination of characters. Spiny rats can only be distinguished as a group. Cuticular scale patterns and cross-sections show more heterogeneity among species, compared to other characters. Medullary cell shape, their arrangement, maximum number of cells in the widest region of the hair, hair dimensions and profiles are also useful in species identification.
\end{abstract}

Keywords: cuticular scales, gerbils, guard hair, medullae patterns, mice, rats

\section{INTRODUCTION}

Epidermal hair is a unique feature of mammals. Anatomy of hairs is known to change according to the habitats in which mammals live, and hence is species-specific and important in taxonomy (Kondo, 2000; Sarkar et al., 2011; Anwar et al., 2012). Identification of species through hair anatomy is useful in many disciplines, such as paleontology, zooarchaeology, anthropology, ecology and forensic science (Marinis and Asprea, 2006).

There are three types of hairs located in different regions of the mammalian body; vibrissae, bristle hairs and coat hairs; of these latter is mostly used in taxonomic studies (Teerink, 1991). Coat hairs are of two types: guard hairs $(\mathrm{GH})$ and under hairs (UH), with the former being of greater taxonomic importance (Marinis and Agnelli, 1993; Teerink, 1991). Of the three guard hair types GH0, GH1 and $\mathrm{GH} 2$, the latter two show more heterogeneity among species and are important in taxonomic studies (Teerink, 1991; Menike et al., 2012). A hair consists of three structural units: outermost cuticle, mid-cortex and innermost medulla (Homan and Genoways, 1978; Hausman, 1920). Of these, cuticular scales and medullae patterns are studied in detail for species identification along with crosssections of hairs. In addition, hair profile and dimensions (length and maximum diameter of hairs) are used (Teerink, 1991; Amerasinghe, 1983).
In Sri Lanka, fifteen species of murine rodents (rats and mice) belonging to eight genera, namely, Bandicota, Mus, Golunda, Srilankamys, Rattus, Madromys, Millardia and Vandeleuria and a single species of gerbil, Tatera tatera are recorded. Of these, one genus and three species are endemic to the island (Table 1). All species of muroid rodents, except Mus booduga, were included in a study on hair anatomy of Sri Lankan mammals (Amerasinghe, 1983). However, since the study dealt with 108 mammal species and subspecies in the country, illustrations were limited to examples and only generic level identification was attempted in the keys, hence in most instances not distinguishing among species.

Here, we characterize dorsal guard hairs of all 16 species of muroid rodents in Sri Lanka providing an improved tool for discriminating among the dorsal guard hairs of these species based on cuticular scale patterns, shapes of cross-sections, medullae patterns, hair profile and dimensions. We also considered a single pair of subspecies, Gollunda ellioti ellioti and G. e. nuwara, because the latter subspecies has spinous hairs while the former has soft hairs (Phillips, 1980). Since cuticular scale patterns, shapes of cross-sections and the form of medullae are not uniform from the tip to the base of guard hairs (Amerasinghe, 1983; Teerink, 1991; Menike et al., 2012), we also report charactervariation along the entire length of the hair.

*Corresponding author's email: suyamam@pdn.ac.lk 


\section{MATERIALS AND METHODS}

Hair samples used in this study were from rodents collected during an island-wide survey of small mammals carried out from 2003-2005, except those of Rattus montanus, $R$. blanfordi, Bandicota indica, $B$. bengalensis and $G$. e. ellioti, which were obtained from the National Museum of Sri Lanka (Table 1). Hair samples of Mus cervicolor and $R$. norvegicus were from both sources. All specimens considered here were adults. Voucher specimens of collected rodents originally deposited in the collection of the Wildlife Heritage Trust (WHT) are now placed in the Department of Zoology, University of Peradeniya, Sri Lanka.

Samples of dorsal hair from one to four specimens from each species and subspecies were used in this study, depending on the availability. Only GH1 and
GH2 were studied as they exhibit considerable variation among species (Teerink, 1991). To observe cuticular scale patterns, cuticular scale imprints were taken on a thin layer of nail polish similar to the method used by Amerasinghe (1983) using a thin solution of Canada balsom in xylene. Cuticular scale patterns of the groove side of the hair were not considered because the nail polish frequently got trapped in the groove and damaged the cast. Cross-sections of hairs were made using thin strips of 'botanical pith' (Amerasinghe, 1983; Teerink, 1991). Nail polish was applied on the pith and the hairs were placed along their longitudinal axis. Another strip of pith was then placed over it, covering the hair. After allowing the nail polish to dry for few minutes, thin transverse sections were cut using a clean, sharp razor blade (Amerasinghe, 1983). The sections were pasted in serial order (from tip to base) on a slide using glue and observed under a stereo-microscope.

Table 1. List of the species and subspecies used in the study with their collection sites and the voucher specimen reference numbers. Underlined numbers are of specimens obtained from National Museum of Sri Lanka; WHT - Wildlife Heritage Trust.

\begin{tabular}{|c|c|c|}
\hline Species & Collection site & $\begin{array}{l}\text { Voucher species reference } \\
\text { number }\end{array}$ \\
\hline$\dagger \dagger$ Mus mayori (Spiny-Rat) & Knuckles, Kottawa & $\begin{array}{l}\text { WHT 6948, WHT 6952, WHT } \\
\text { 6883, WHT } 6946\end{array}$ \\
\hline Mus booduga (Common Indian Field- Mouse) & Girithale & WHT M 01 \\
\hline$\dagger \dagger$ Mus fernandoni (Ceylon Spiny-Mouse) & Peradeniya & WHT 6876, WHT 6880 \\
\hline Mus musculus (Indian House-Mouse) & Knuckles & WHT M 84 \\
\hline Mus cervicolor (Ceylon Field-Mouse) & $\begin{array}{l}\text { Kodagoda, } \\
\text { Chankavaly }\end{array}$ & $\begin{array}{l}\text { WHT M } 82, \\
71 . S\end{array}$ \\
\hline Vandeleuria oleracea (Long-tailed Tree mouse) & Agra Arboretum & WHT 6940 \\
\hline Rattus norvegicus (Brown Rat) & Colombo, Knuckles & $\frac{\text { 67.C, }}{\text { WHT } 6942}$ \\
\hline Rattus rattus (Common House rat) & $\begin{array}{l}\text { Horton plains, } \\
\text { Girithale }\end{array}$ & $\begin{array}{l}\text { WHT M } 029 \text {, } \\
\text { WHT M } 02\end{array}$ \\
\hline$\dagger \dagger$ Rattus montanus (Nillu Rat) & West-Haputhale & $\underline{176 . \mathrm{D}}$ \\
\hline Madromys blanfordi (White-tailed Rat) & $\begin{array}{l}\text { Helawe wawa eastern } \\
\text { province }\end{array}$ & $\underline{68 . F}$ \\
\hline Bandicota indica (Indian Bandicoot) & Colombo & $\underline{62 . C}$ \\
\hline Bandicota bengalensis (Indian Mole-Rat) & Mathugama & $\underline{63 . g}$ \\
\hline$\uparrow$ Srilankamys ohiensis (Ceylon Bi-coloured Rat) & Horton plains & WHT 6943 \\
\hline Millardia meltada (Indian Soft-furred Field rat) & Udawalawe & WHT 6925 \\
\hline Golunda ellioti ellioti (Indian Bush-Rat) & Gammaduwa & $\underline{75 * \mathrm{~A}}$ \\
\hline$\dagger \dagger \dagger$ G. e. nuwara (Ceylon Bush-rat) & Horton & WHT M 141 \\
\hline Tatera tatera (Ceylon gerbil) & Yala & WHT M 05 \\
\hline
\end{tabular}

Endemic $\dagger$ Genus $\dagger \uparrow$ species or $\uparrow \dagger \uparrow$ subspecies 
Medullae were observed mounted in $70 \%$ alcohol. In few species (B. indica, B. bengalensis and $G$. $e$. ellioti) the medullae were cleared in liquid paraffin prior to observation (Amerasinghe, 1983; Teerink, 1991). Five hairs from each individual were used to observe cuticles, medullae and cross-sections.

Photomicrographs of cuticular scales, crosssections and medullae were taken using a USB camera fixed to a stereo-microscope. Illustrations of cross-sections were made in Adobe Photoshop raster graphic editor. Measurements of hairs were made using Image-J software. Length and maximum width of fifteen hairs of each hair-type (GH1 and GH2) were measured from each species. Nomenclature of hair anatomy follows Teerink (1991) and Amerasinghe (1983).

\section{RESULTS}

\section{Hair profile}

All the rodents in the study have GH1, GH2 and under hair except spiny rats (M. mayori and $M$. fernandoni) and M. cervicolor, which lack GH2. Spiny rats along with G. e. ellioti also differ from the other species by bearing spinous GH1.

\section{Cuticular scale patterns}

Altogether five cuticular scale patterns: irregular wave, petal, mosaic, diamond and chevron are present in both $\mathrm{GH} 1$ and $\mathrm{GH} 2$ of species and subspecies studied here (Fig. 1). All species have more than one of the above scale patterns through the length of the hair. Although the cuticular scale patterns belong to one of the above broad categories, the shapes, sizes and arrangement of scales of both $\mathrm{GH} 1$ and $\mathrm{GH} 2$ are characteristic of each species and subspecies, except for those of two spiny rats.

In all the species considered here, the cuticular scale patterns take an irregular wavy appearance towards the tip of the shield and the base of the shaft of both GH1 and GH2. Hairs of all species have broad or elongated petal scales between the irregular wave pattern of tip and base of hairs except M. blanfordi, M. musculus, T. tatera and $\mathrm{GH} 1$ of $M$. booduga. Both GH1 and GH2 of $M$. blanfordi and T. tatera have characteristic chevron wave pattern while GH1 of $M$. musculus and $M$. booduga have mosaic scales and $\mathrm{GH} 2$ of $M$. musculus has both mosaic and chevron scales. Chevron pattern is also seen in $\mathrm{GH} 2$ of M. meltada, G. e. nuwara and GH1 of S. ohiensis. Both GH1 and GH2 of $R$. rattus, $R$. norvegicus and $R$. montanus have diamond scales.
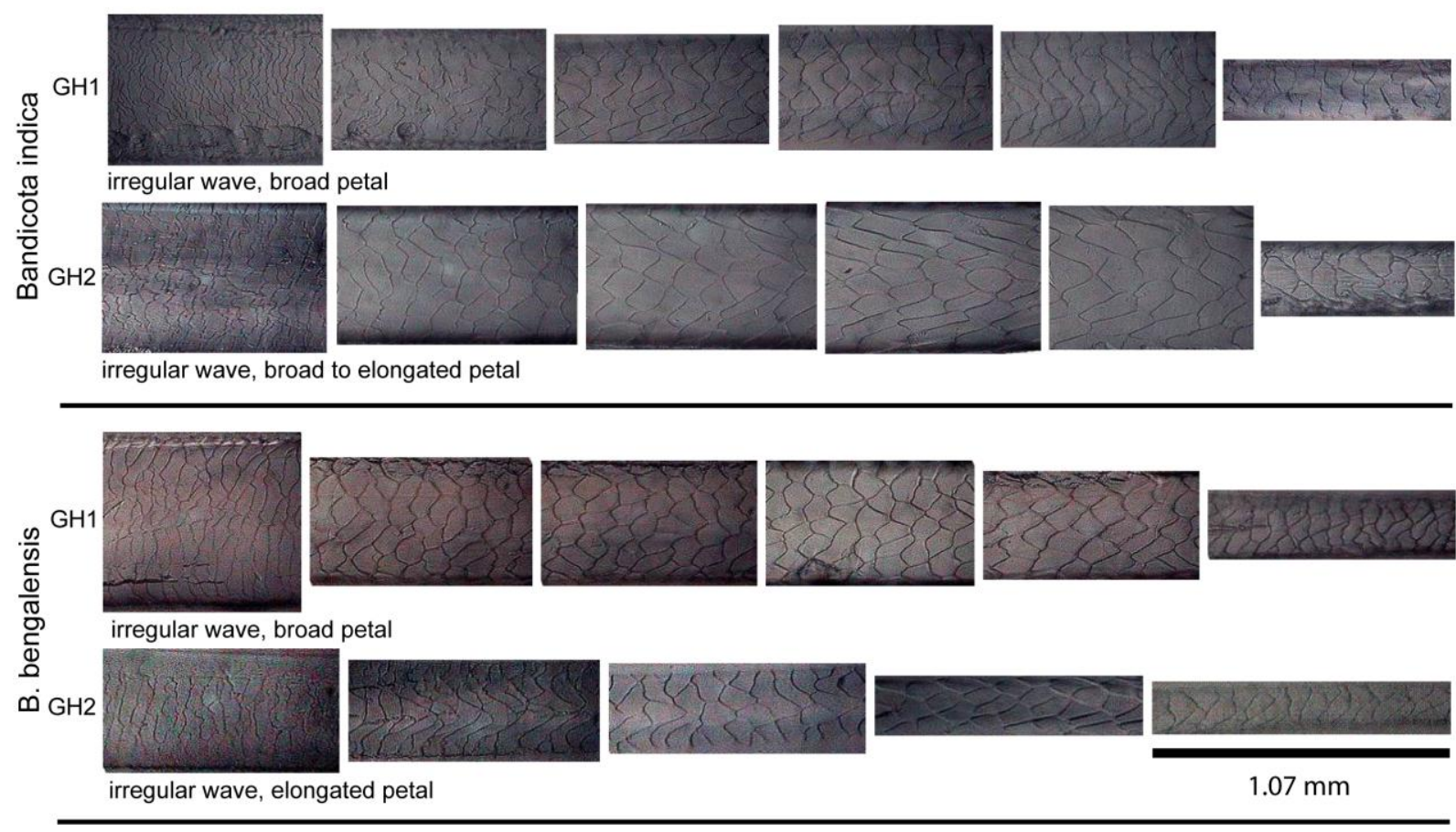

Figure 1. Distinguishing cuticular scale patterns of species of Sri Lankan muroid rodents. Each photograph was taken under medium power under a light microscope (10X10 power) and is $1.07 \mathrm{~mm}$ in length. 

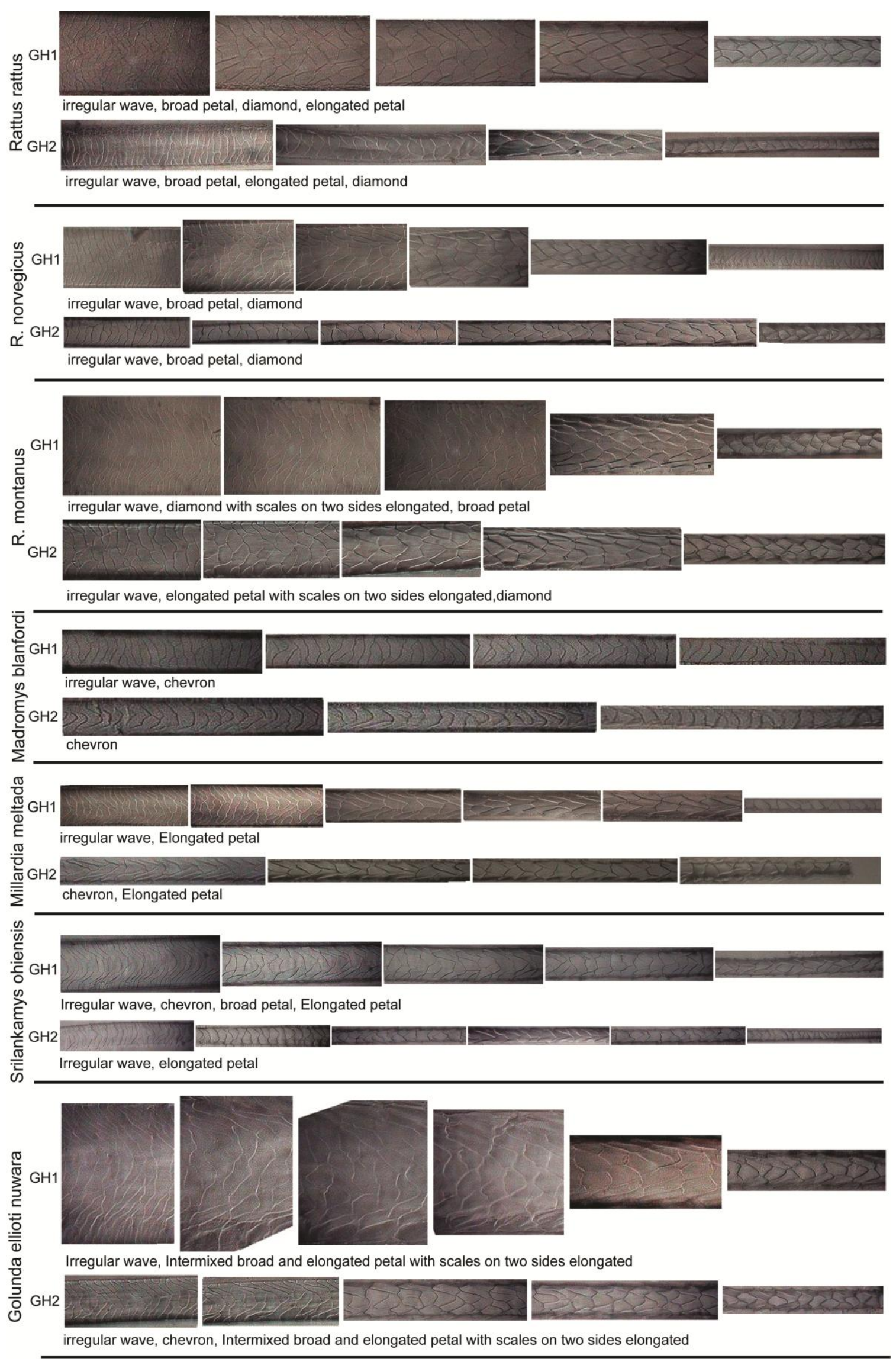

Figure 1. continued 

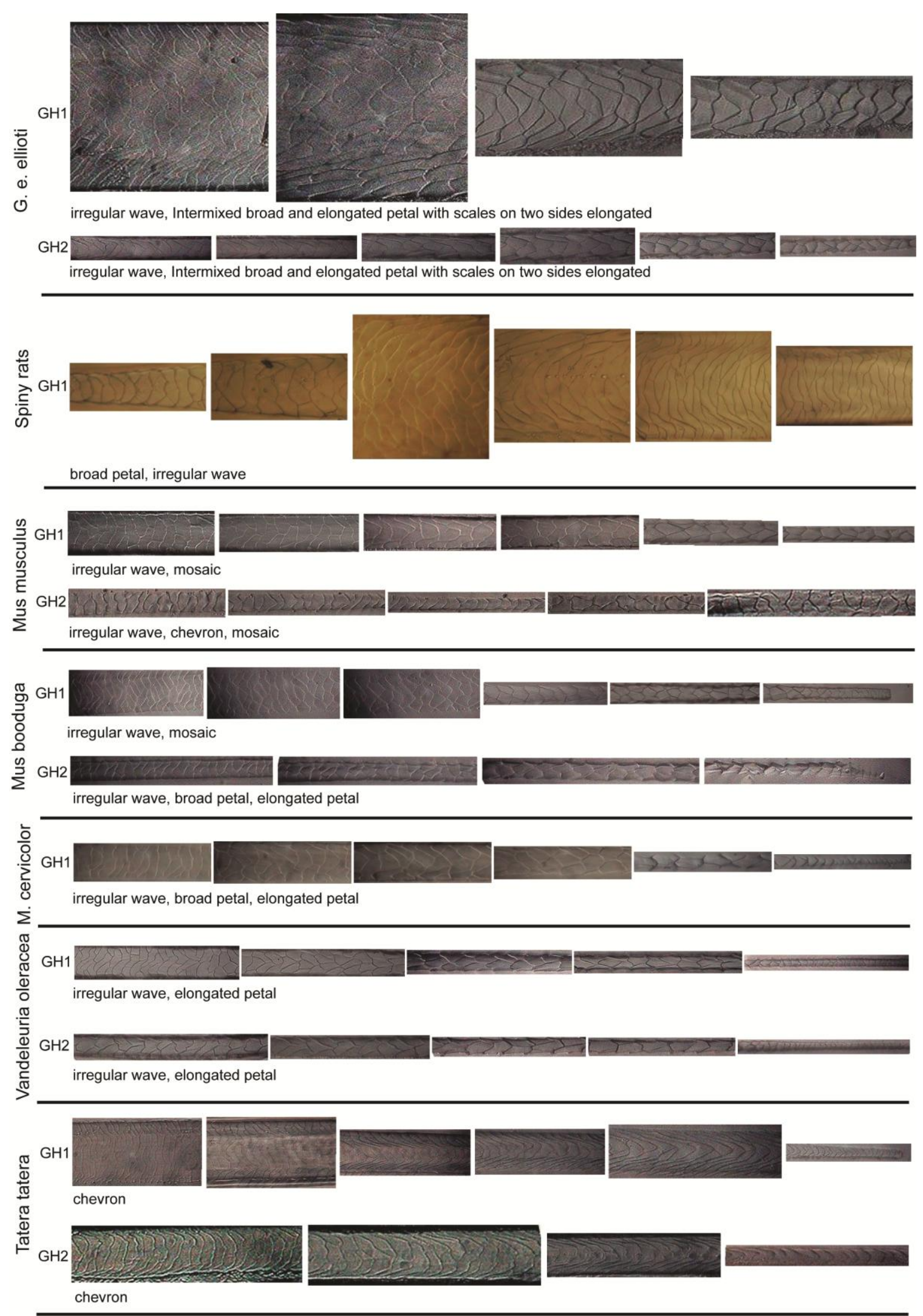

Figure 1. continued 


\section{Cross-sections}

Cross-sections of both GH1 and GH2 of all species are of circular or oval shapes towards the tip and base of the hairs except the tip of GH1 in spiny rats, which has a characteristic triconcave shape and tip of GH1 in G. e. ellioti, which has triangular and square shaped cross-sections. Between the tip and base of both GH1 and GH2, shapes of cross-sections vary among species (Table 2).

Altogether there are five shapes present in the mid region: concavo-convex, plano-concave, oblong, biconcave and dumbbell. Concavo-convex shape is common to both GH1 and GH2 of all the species except for GH1 and GH2 of B. indica and GH2 of $M$. booduga. Plano-concave shape is also found in many species; both GH1 and GH2 of R. montanus, GH1 of $B$. indica, $R$. rattus, spiny rats, M. booduga and $T$. tatera and in $\mathrm{GH} 2$ of $G$. e. ellioti. Oblong shape is seen in both $\mathrm{GH} 1$ and $\mathrm{GH} 2$ of $B$. indica, $B$. bengalensis, $R$. montanus, M. blanfordi, T. tatera and $\mathrm{GH} 2$ of $M$. booduga. Biconcave shape is restricted to few species: GH2 of $B$. indica, R. rattus and $R$. norvegicus, M. booduga and GH1 of $M$. musculus. Dumbbell shape is only seen in GH1 of G. ellioti subspecies.

Table 2. Cross-sections of guard hairs (GH1 and GH2) of Sri Lankan muroid rodent species.

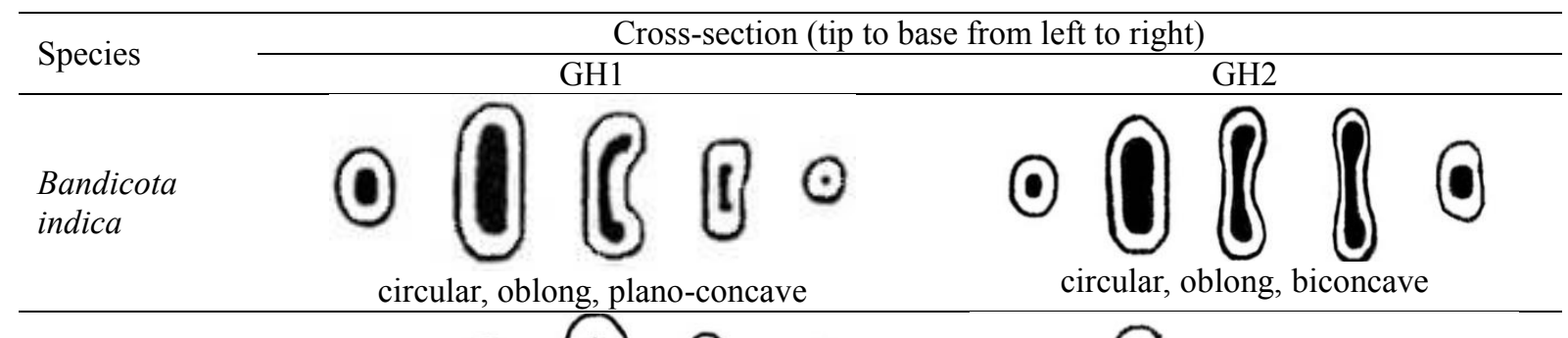

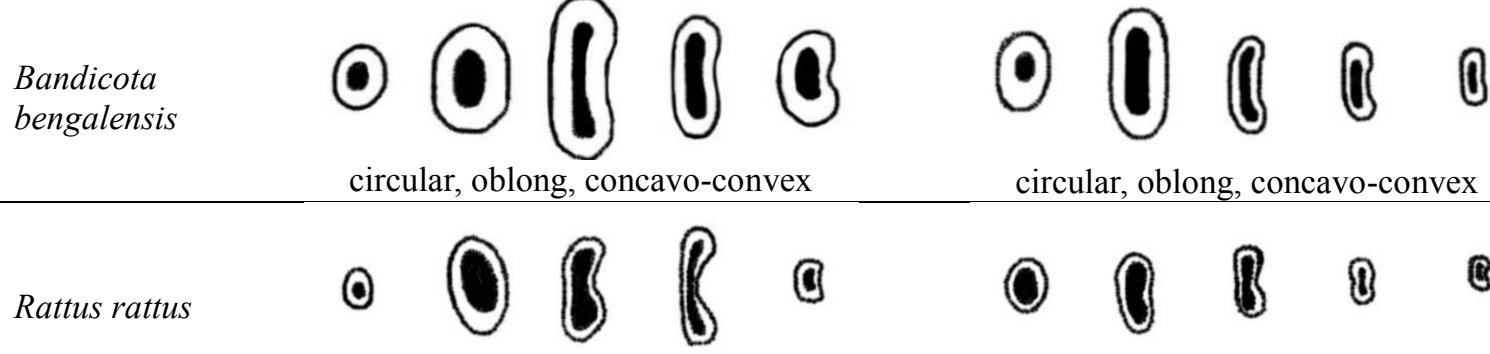

circular, oval, plano-concave, concavo-convex

oval, concavo-convex, biconcave

\begin{tabular}{|c|c|c|}
\hline $\begin{array}{l}\text { Rattus } \\
\text { norvegicus }\end{array}$ & $\circlearrowleft \circlearrowleft$ & (0) 000 \\
\hline $\begin{array}{l}\text { Rattus } \\
\text { montanus }\end{array}$ & (0) & (O) 000 \\
\hline \multirow[t]{2}{*}{$\begin{array}{l}\text { Madromys } \\
\text { blanfordi }\end{array}$} & 0 & 0 \\
\hline & oval, concavo-convex, oblong & circular, concavo-convex, oblong \\
\hline \multirow[t]{2}{*}{$\begin{array}{l}\text { Millardia } \\
\text { meltada }\end{array}$} & $B$ & $\Omega$ \\
\hline & circular, concavo-convex & circular, concavo-convex, oval \\
\hline
\end{tabular}




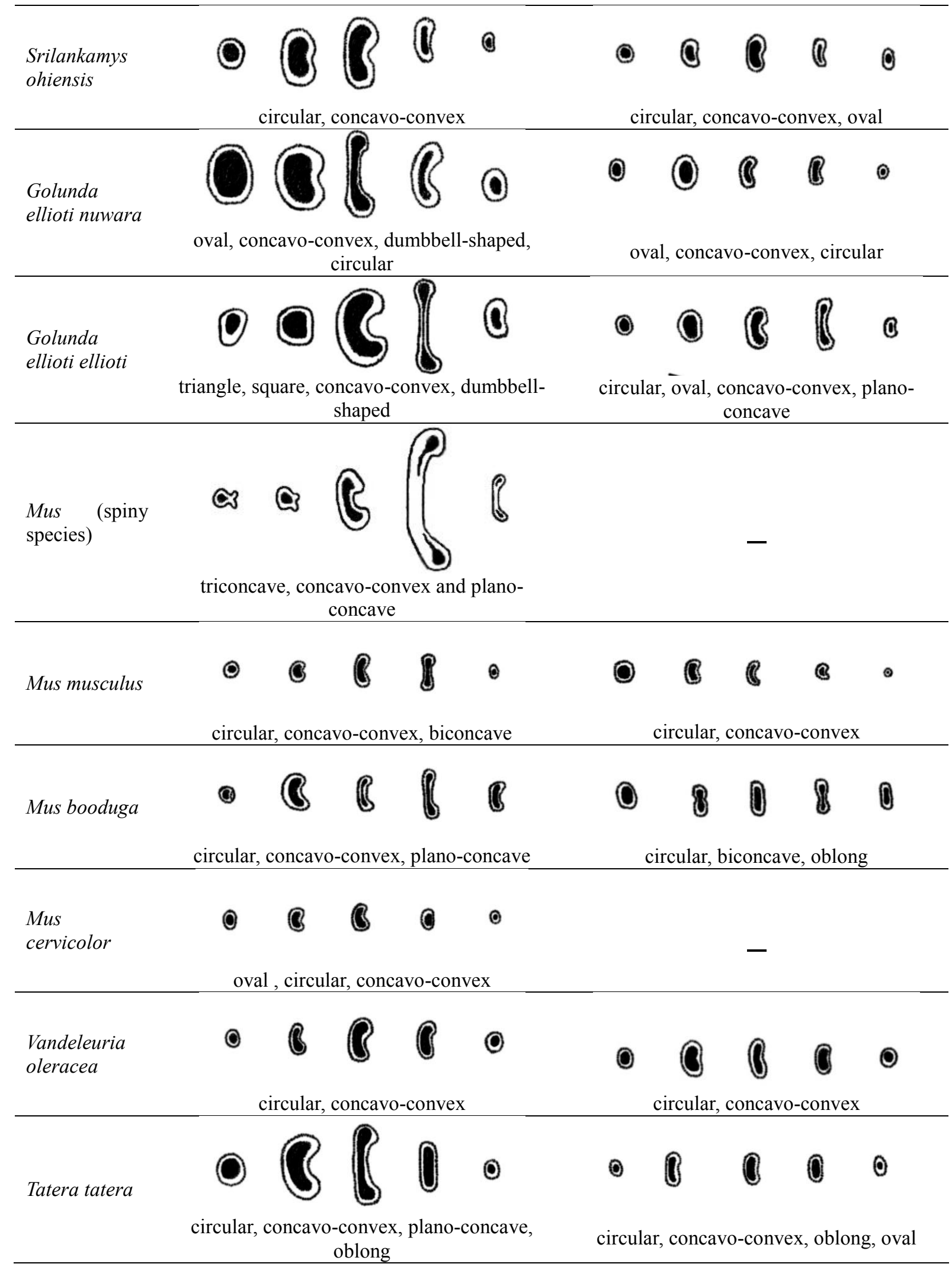




\section{Medullae patterns}

Medullae of all species are unicellular towards the tip and the base of both GH1 and GH2 and multicellular in the middle (Table 3 ). GH1 of spiny rats, $G$. e. nuwara and $G$. e. ellioti have characteristic transverse lattice medullae while others have circular to oval shaped cells giving a honeycomb appearance to the medullae. Some have random honeycomb appearance to the medullae $(\mathrm{GH} 1$ and $\mathrm{GH} 2$ of $B$. indica, $B$. bengalensis, GH1 of $R$. rattus, $R$. norvegicus, $R$. montanus, S. ohiensis, M. booduga and GH2 of $G$. $e$. ellioti). Medullary cells in the mid region of $\mathrm{GH} 1$ of $B$. indica are concentrated on the two sides with no cells in the middle, which is unique to the species.

Table 3. Medullae patterns useful in identification of species of Sri Lankan muroid rodents. Each photograph was taken under medium power of a light microscope (10X10 power) and is $1.07 \mathrm{~mm}$ in length.

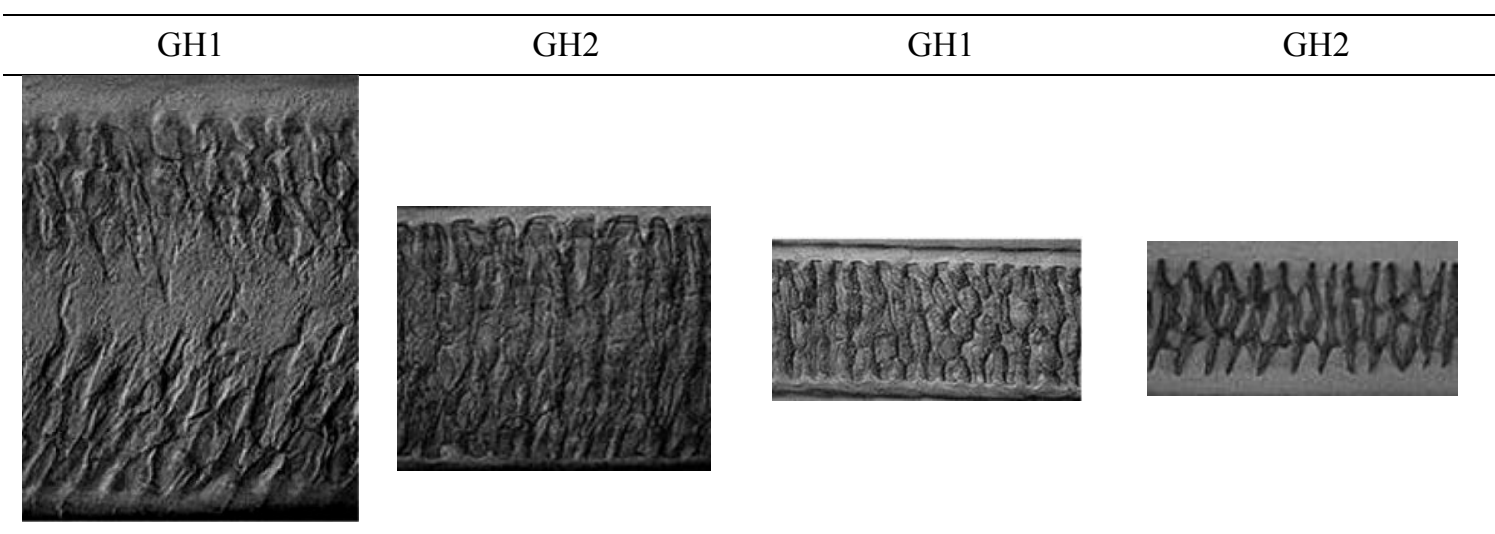

Bandicota indica

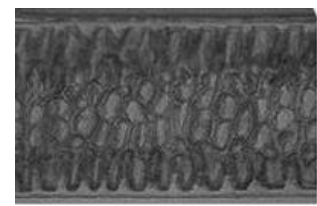

Bandicota bengalensis
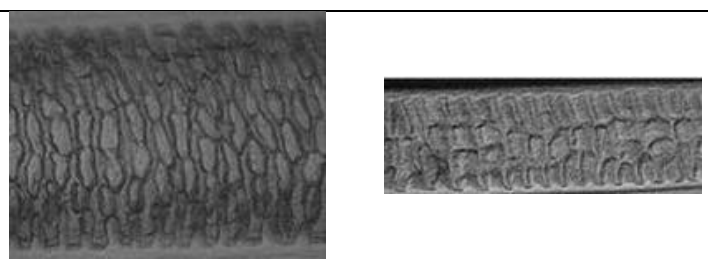

Rattus norvegicus
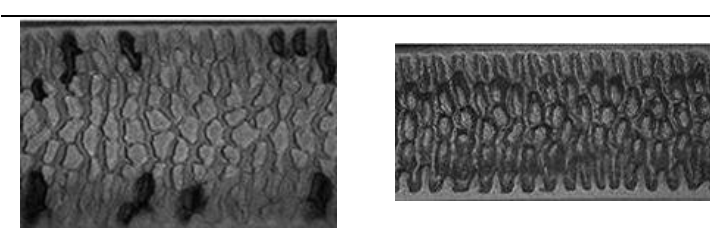

Rattus montanus
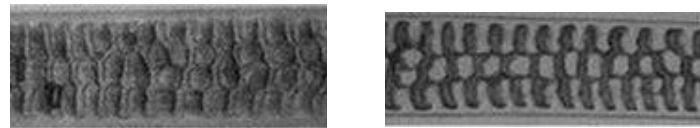

Millardia meltada
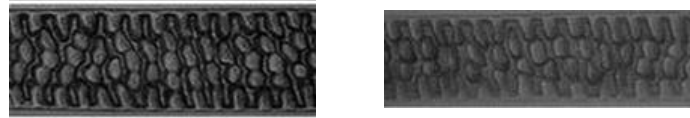

Madromys blanfordi
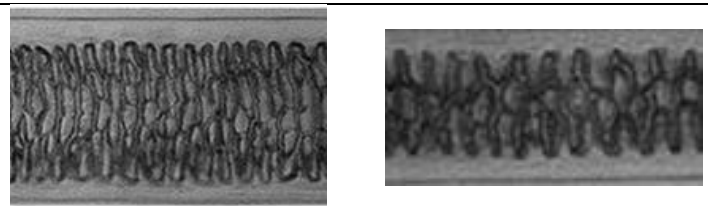

Srilankamys ohiensis 

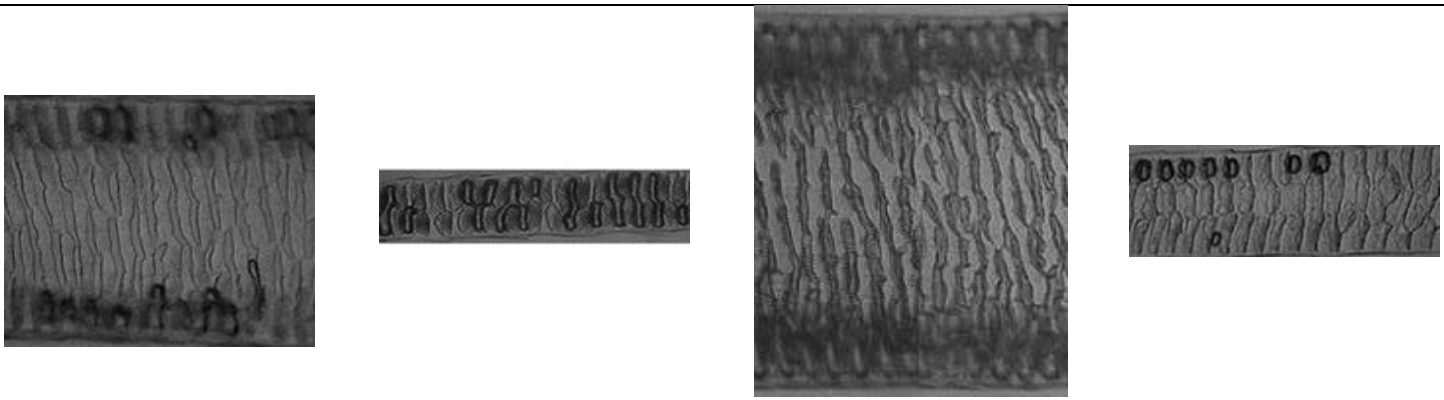

Golunda ellioti nuwara

Golunda ellioti ellioti
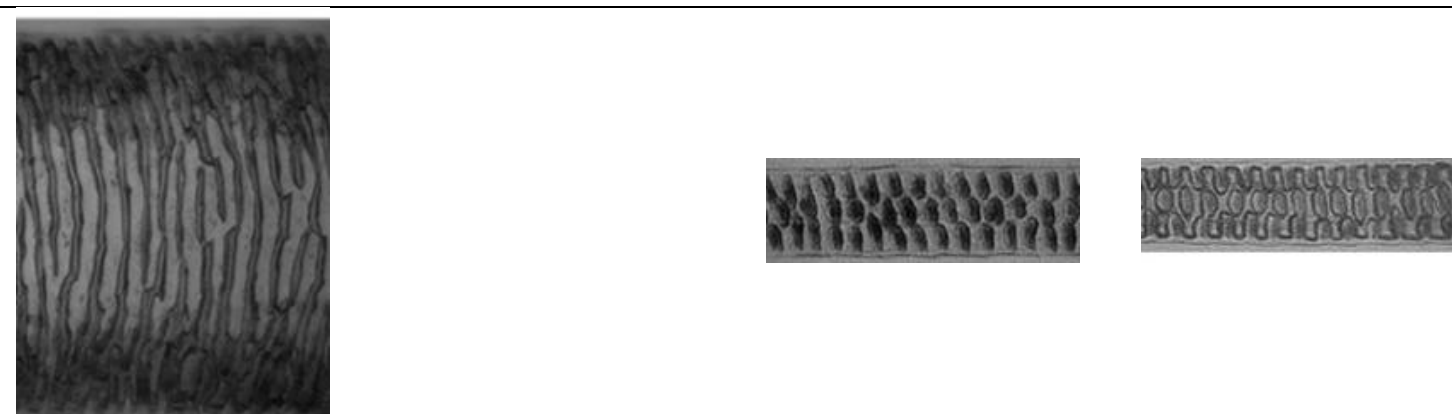

Mus (spiny species)

Mus musculus
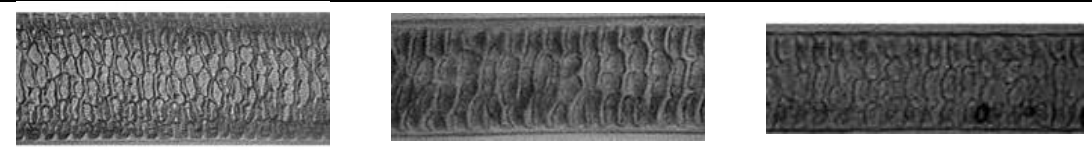

Mus booduga

Mus cervicolor
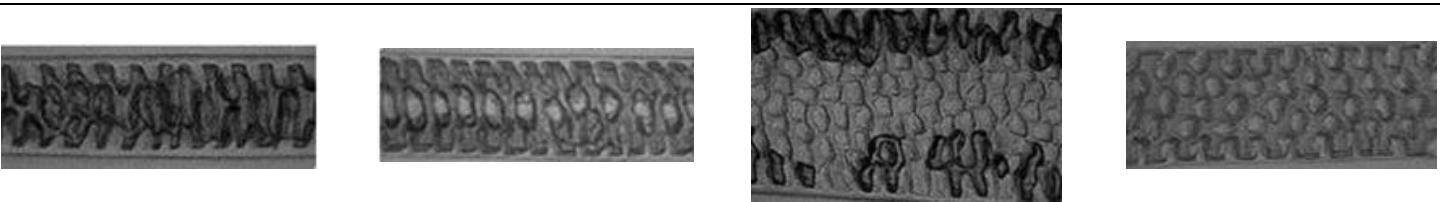

Tatera tatera

$1.07 \mathrm{~mm}$

\section{Length and maximum diameter}

The dimensions of the hairs can be used in combination with other characters to distinguish species (Table 4). Species can be broadly categorized into groups based on lengths or maximum widths of $\mathrm{GH} 1$ and $\mathrm{GH} 2$; for example, both $\mathrm{GH} 1$ and $\mathrm{GH} 2$ shorter than $10 \mathrm{~mm}(M$. booduga, M. musculus); GH1 shorter than $10 \mathrm{~mm}$
(M. booduga, M. musculus, M. cervicolor, $M$. fernandoni); GH1 above $20 \mathrm{~mm}$ (B. indica, $R$. montanus); maximum widths of GH1 is between 170-240 $\mu \mathrm{m}$ (M. fernandoni, B. indica); GH2 below $10 \mathrm{~mm}$ ( $V$. oleracea, T. tatera, M. booduga, M. musculus); GH2 maximum width below $50 \mu \mathrm{m}$ (all except $B$. indica, $B$. bengalensis and $R$. montanus). 
Table 4. Length and maximum width of muroid rodents in Sri Lanka (range, mean and standard deviation).

\begin{tabular}{|c|c|c|c|c|}
\hline \multirow{2}{*}{ Species } & \multicolumn{2}{|c|}{ GH1 } & \multicolumn{2}{|c|}{$\mathrm{GH} 2$} \\
\hline & $\begin{array}{l}\text { Length } \\
(\mathrm{mm})\end{array}$ & $\begin{array}{l}\text { Maximum width } \\
(\mu \mathrm{m})\end{array}$ & $\begin{array}{l}\text { Length } \\
(\mathrm{mm})\end{array}$ & $\begin{array}{l}\text { Maximum } \\
\text { width }(\mu \mathrm{m})\end{array}$ \\
\hline Bandicota indica & $24.7-33.8(29.1 \pm 3.1)$ & $170-230(200 \pm 19)$ & $19.8-27.5(24.3 \pm 2.5)$ & $60-140(95 \pm 20)$ \\
\hline B. bengalensis & $12.3-24.6(16.4 \pm 3.7)$ & $80-120(96 \pm 11)$ & $7.9-12.8(10.9 \pm 1.5)$ & $40-80(61 \pm 13)$ \\
\hline Rattus rattus & $14.3-24.0(19.6 \pm 3.3)$ & $60-90(69 \pm 94)$ & $10.1-23.5(16 \pm 3.2)$ & $30-50(41 \pm 8)$ \\
\hline R. norvegicus & $14.6-20.74(16.7 \pm 1.6)$ & $50-70(65 \pm 6)$ & $15.2-16.6(15.9 \pm 0.4)$ & $30-50(41 \pm 7)$ \\
\hline R. montanus & $20.1-30.6(25.6 \pm 2.6)$ & $90-130(113 \pm 11)$ & $9.3-29.1(21.7 \pm 4.6)$ & $60-90(74 \pm 9)$ \\
\hline Madromys blanfordi & $11.4-19.6(13.3 \pm 2.1)$ & $40-50(47 \pm 5)$ & $11.0-14.7(12.5 \pm 1.1)$ & $20-30(22 \pm 4)$ \\
\hline Millardia meltada & $11.5-14.3(12.9 \pm 0.8)$ & $30-60(47 \pm 9)$ & $7.1-12.03(9.5 \pm 1.7)$ & $20-40(27 \pm 6)$ \\
\hline Srilankamys ohiensis & $12.2-13.1(12.7 \pm 0.3)$ & $60-80(7 \pm 9)$ & $9.2-14.11(10.9 \pm 1.4)$ & $30-50(37 \pm 8)$ \\
\hline $\begin{array}{l}\text { Gollunda ellioti } \\
\text { nuwara }\end{array}$ & $14.0-21.1(17.3 \pm 2.5)$ & $60-90(82 \pm 9)$ & $12.9-17.1(16.0 \pm 1.4)$ & $30-50(42 \pm 7)$ \\
\hline G. ellioti ellioti & $9.0-12.9(11.1 \pm 0.9)$ & $80-200(146 \pm 43)$ & $7.8-13.2(11.0 \pm 1.6)$ & $30-50(37 \pm 8)$ \\
\hline Mus mayori & $7.4-16.1(12.1 \pm 2.4)$ & $90-510(297 \pm 117)$ & - & - \\
\hline M. fernandoni & $8.21-9.5(8.8 \pm 0.5)$ & $190-240(217 \pm 14)$ & - & - \\
\hline M. musculus & $4.5-6.1(5.3 \pm 0.5)$ & $40-50(44 \pm 5)$ & $4.1-5.1(4.6 \pm 0.3)$ & $30-50(33 \pm 6)$ \\
\hline M. booduga & $4.6-5.1(4.9 \pm 0.1)$ & $50-70(63 \pm 8)$ & $3.0-4.7(3.9 \pm 0.6)$ & $20-40(28 \pm 8)$ \\
\hline M. cervicolor & $4.2-5.82(4.8 \pm 0.5)$ & $20-50(31 \pm 11)$ & - & - \\
\hline Vandeleuria oleracea & $7.6-10.8(9.0 \pm 0.8)$ & $30-50(36 \pm 6)$ & $6.0-8.6(7.4 \pm 0.8)$ & $20-40(29 \pm 6)$ \\
\hline Tatera tatera & $10.2-11.3(10.6 \pm 0.4)$ & $60-80(67 \pm 7)$ & $7.6-9.02(8.3 \pm 0.6)$ & $20-50(29 \pm 9)$ \\
\hline
\end{tabular}

\section{Key for hair identification}

The key is based on cuticular scale patterns, crosssections, medullae patterns, hair profile and dimensions of GH1 and GH2 hairs described above. Characters shared by all species such as irregular wave cuticular scale pattern and circular to oval cross-sections towards the tip of the shield and the base of the shaft of both GH1 and GH2 (except GH1 of spiny rats and $G$. e. ellioti) are excluded when developing the key. 
Key to the identification of dorsal guard hairs of muroid rodents of Sri Lanka (to be used in conjunction with microphotographs of cuticular scales, medullae and illustrations of cross-sections)

1. a. GH1 with transverse lattice medullae. 2

b. GH1 with honeycomb lattice medullae

2. a. Only GH1 present; GH1 cross-sections are tri-concave, concavo-convex and plano-concave

Mus mayori / Mus fernandoni

b. Both GH1 and GH2 are present; GH1 cross-sections include concavo-convex and dumbbell shaped 3

3. a. Square shaped and triangular shaped cross-sections in shield towards tip of GH1; GH1 are short (maximum width 9.0-12.9 mm) and thick (maximum width $80-200 \mu \mathrm{m}$ ); GH2 cross-sections are of concavo-convex shape Golunda ellioti ellioti

b. Oval and concavo-convex cross-sections in shield towards tip of GH1; GH1 are long (14.0-21.1 mm) and slender (maximum width $60-90 \mu \mathrm{m}$ ); GH2 cross-sections include plano-concave in addition to concavo-convex

Golunda ellioti nuwara

4. a. Chevron scales throughout $\mathrm{GH} 1$ and $\mathrm{GH} 2$ 5

b. Scales otherwise

5. a. GH1 have concavo-convex and oblong cross-sections along with plano-concave cross-sections towards the base; GH2 cross-sections are concavo-convex and oblong; GH1 medulla has more than 6 rows of cells in the widest region

Tatera tatera

b. Cross-sections are concavo-convex and oblong in both GH1 and GH2; medulla of GH1 has 5 or less than 5 rows of cells in the widest region

Madromys blanfordi

6. a. Diamond shaped scales present in both GH1 and GH2

b. Scales otherwise

7. a. GH2 cross-sections include concavo-convex and biconcave shapes; both GH1 and GH2 are slender (maximum width GH1: 50-90 $\mu \mathrm{m}$; GH2: 30-50 $\mu \mathrm{m}$ )

b. GH2 cross-sections include concavo-convex, plano-concave, oblong; Both GH1 and GH2 are broad (maximum width GH1: 90-130 $\mu \mathrm{m}$; GH2: 60-90 $\mu \mathrm{m}$ )

Rattus montanus

8. a. GH1 cross-sections include both concavo-convex and plano-concave shapes

Rattus rattus

b. Only concavo-convex shaped cross-sections in GH1

Rattus norvegicus

9. a. Guard hairs (both GH1 and GH2 or GH1 in species where GH2 is absent) with concavo-convex cross-sections only

b. Cross-sections otherwise 


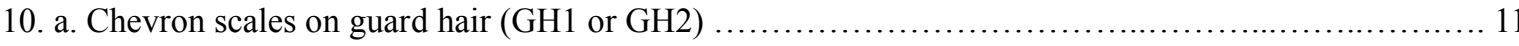

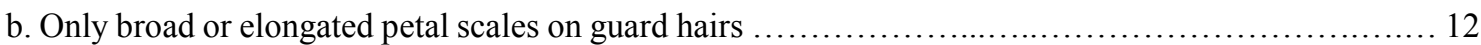

11. a. GH1 with honey-comb lattice medulla; slender $(30-60 \mu \mathrm{m}) \mathrm{GH} 1$

Millardia meltada

b. GH1 with random honey-comb lattice medulla with elongated cells interspersed; thick $(60-80 \mu \mathrm{m})$ GH1 Srilankamys ohiensis

12. a. Only GH1 is present, GH2 is absent; Short (4.2- $5.82 \mathrm{~mm}) \mathrm{GH} 1$ hairs Mus cervicolour

b. Both GH1 and GH2 are present; relatively longer (7.6-10.8 mm) GH1 hairs Vandeleuria oleracea

13. a. Long and thick GH1 (12-34 mm/ 80-230 $\mu \mathrm{m})$ and GH2 (7-28 mm/40-140 $\mu \mathrm{m})$; Oblong cross-sections present in both $\mathrm{GH} 1$ and $\mathrm{GH} 2$

b. Short and slender GH1 (4-6 $\mathrm{mm} / 40-70 \mu \mathrm{m})$ and GH2 $(3-5 \mathrm{~mm} / 20-50 \mu \mathrm{m})$; cross-sections otherwise or with oblong shape cross-section in $\mathrm{GH} 2$ only

14. a. Oblong, plano-concave cross-section in GH1; oblong, biconcave cross-sections in GH2; medullary cells concentrated on the two sides in the mid broader region of $\mathrm{GH} 1$; GH2 with broad and elongated petal scales; long and thick GH1 $(24.7-33.8 \mathrm{~mm} / 170-230 \mu \mathrm{m})$ and GH2 $(19.8-27.5 \mathrm{~mm} / 60-140 \mu \mathrm{m})$

Bandicota indica

b. Only oblong and concavo-convex cross-sections in GH1 and GH2; Medullary cells fill the whole medulla in the mid region of GH1; only elongated petal scales on GH2; Short and slender GH1 $(12.3-24.6 \mathrm{~mm} / 80-120 \mu \mathrm{m})$ and GH2 (7.9-12.8 $\mathrm{mm} / 40-80 \mu \mathrm{m})$

Bandicota bengalensis

15. a. Thick GH1 (50-70 $\mu \mathrm{m})$ with plano-concave and concavo-convex cross-sections; GH2 with Oblong and biconcave cross-sections; broad and elongated petal scales Mus booduga

b. Slender GH1 (40-50 $\mu \mathrm{m})$ with concavo-convex and biconcave cross-sections; GH2 with concavoconvex cross-sections and chevron and mosaic scales

Mus musculus

\section{DISCUSSION}

The anatomy of dorsal guard hairs, GH1 and GH2, facilitate the identification of all the species of muroid rodents (rats, mice and gerbils) in Sri Lanka, except the two species of spiny rats (Mus mayory and $M$. fernandoni), which can be distinguished together from other species. All the characters studied (cuticular scale patterns, medullae patterns, cross-sections, hair profile, length and maximum width) are useful in distinguishing species.

Scale patterns are highly heterogeneous among species. All the species considered here have irregular wavy scale pattern towards the tip of the shield and the base of the shaft of both GH1 and GH2. As other studies have reported (Cavia, 2008; Teerink, 1991; Menike et al., 2012) cuticular scale patterns vary from the base to the tip of hairs in the species studied. Hence, a given species has more than a single scale pattern along the length of a hair. In most species, patterns vary between $\mathrm{GH} 1$ and $\mathrm{GH} 2$. As other studies also have reported, for reliable identification of species, scale patterns in the medial part of the shaft should be used (Amerasinghe, 1983; Chehébar and Martìn, 1989; Fernández and Rossi, 1998). Cuticular scale patterns of most of the species included here are broad or elongated petal, though the sizes, shapes and the arrangement of the scales differ among the species. Some species, however, can be clearly and easily distinguished from others using cuticular scales alone; for example characteristic chevron scales on GH1 and GH2 of M. blanfordi and $T$. tatera; diamond scales in Rattus species.

Cross-sections of guard hairs vary to a great extent among species and are an important character for distinguishing species. Cross-sections of the tip of 
GH1 are useful to distinguish spiny rats and G. e. ellioti from other species. Spiny rats have triconcave cross-sections and $G$. e. ellioti has triangular and square shaped cross-sections while other species have circular to oval cross-sections. In between the tip and base, cross-sections take concavo-convex, plano-concave, biconcave, dumbbell and oblong shapes in the species studied. Presence or absence of these shapes in crosssections is useful in identification of each species.

Medullae pattern of the guard hairs can also be used for identification of species in combination with other characters. There are two major types of medullae pattern; transverse lattice and honeycomb lattice. Honeycomb lattice is random in some species, which can be used as an identifying character. Number of medullary cell rows in the widest part of the hair is another useful feature for species identification (Amerasinge, 1983; Teerink, 1991), though there are instances where the number of maximum rows reported differ between studies, for example 4 (Teerink, 1991) and 3-4 (Amerasinge, 1983) for $M$. musculus.

In addition, lengths and maximum widths of guard hairs, and hair profiles can be used to distinguish species. The presence or absence of different types of hairs, abundance of each type of hair, and presence of spinous hairs are some of the hair profile features that can aid in species differentiation. For example, spiny rats and $M$. cervicolor lack GH2; GH2 is less abundant compared to GH1 in M. musculus and M. booduga, while others have similar numbers of each; spiny rats and G. e. ellioti have spinous GH1.

We considered a single pair of subspecies; $G$. e. ellioti and $G$. e. nuwera, since the former has spinous hairs and the latter has soft hair (Phillips, 1980). The study revealed that the two subspecies could be clearly differentiated from each other using their microscopic hair anatomy. They differ from each other by characteristic cuticular scale patterns (Fig. 1), cross-sections (Table 2) and hair dimensions (Table 4). This is the first instance a difference in hair anatomy is reported at subspecies level.

Hair anatomy reported here can be used for species-identification in ecological surveys such as density, population or habitat surveys using hair tubes and for investigating food habits of carnivores using hair samples from scats (Amerasinghe and Ekanayake, 1990; Dickman, 1986; Toth, 2002; Finnegan et al., 2007; Bertolino et al., 2009). It can also be used to aid in identification of museum specimens.

\section{ACKNOWLEDGEMENTS}

We are grateful to Mrs. Sanuja Kasthuriarachchi, the Director, and Dr. Manori Goonatilake, the Assistant Director of Department of National Museum, Sri Lanka for providing several hair samples used in this study.

\section{REFERENCES}

Amerasinghe, F.P. (1983). The structure and identification of the hairs of the mammals of Sri Lanka. Ceylon Journal of Science (Biological Sciences) 16 (1\&2):76-125.

Amerasinghe F.P. and Ekanayake, U.B. (1990). Food habits of the Leapard (Panthera pardus fusca) in Sri Lanka. Ceylon journal of Science (Biological Sciences) 21(1):17-24.

Anwar, M.B., Nadeem, M.S., Beg, M.A., Kayani, A.R., Muhammad, G. (2012). A photographic key for the identification of mammalian hairs of prey species in snow leopard (Panthera uncia) habitats of Gilgit-Bailistan province of Pakistan. Pakistan Journal of Zoology 44(3):737-743.

Bertolino, S., Wauters, L., Pizzul, A., Molinari, A., Lurz, P. and Tosi, G. (2009). A general approach of using hair-tubes to monitor the European red squirrel: A method applicable at regional and national scales. Mammalian Biology 74:210-218.

Cavia, R., Andrade, A., Zamero, M.E., Ferna'ndez, M.S., Muschetto, E., Cueto G.R. and Sua'rez O. V. (2008). Hair structure of small rodents from central Argentina: A tool for species identification. Mammalia 72: 35-43.

Chehébar C. and Martı'n S. (1989). A guide to the microscopic identification of hairs from patagonian mammals. Donana Acta Vertebrata 16: 247-291.

Dickman, C. (1986). A method for censusing small mammals in urban habitats. Notes from the Mammal Society. 53: 631-635.

Fernández, G.J. and Rossi, S.M. (1998). Medullar type and cuticular scale patterns of hairs of rodents and small marsupials from the Monte Scrubland (San Luis Province, Argentina). Mastozoologia Neotropical 5(2):109-116.

Finnegan, L., Hamilton, G., Perol, J. and Rochford J. (2007). The use of hair tubes as an indirect method for monitoring red and grey squirrel populations. Biology and Environment: Proceedings of the Royal Irish Academy 107B(2): 55-60.

Homan, J.A. and Genoways, H.H. (1978). An analysis of hair structure and its phylogenetic implications among heteromyid rodents. Journal of Mammalogy 59(4): 740-760.

Hausman, L.A. (1920). Structural characters of the hair of mammals. The American Naturalist 
54(635): 496-523.

Kondo, K. (2000). The diversity of mammalian pelage. Journal of Faculty of Agriculture. Hokkaido University 70(1): 9-17.

Marinis, A.M.D. and Agnelli, P. (1993). Guide to the microscope analysis of Italian mammals hairs: Insectivora, Rodentia and Lagomorpha. Italian Journal of Zoology 60(2): 225-232.

Marinis A.M. and Asprea A. (2006). Hair identification key of wild and domestic ungulates from southern Europe. Wildlife Biology 12: 305-320.

Menike, U., Manawadu, D. and Meegaskumbura, S. (2012). Identification of Sri Lankan shrews using hair anatomy. Ceylon Journal of Science (Biological Sciences) 41(1): 45-66.
Phillips, W.W.A. (1980). A manual of the mammals of Sri Lanka. Wildlife and Nature Protection Society of Sri Lanka, Colombo, 389+xxxv Pp.

Sarkar, P.S., Krishna, J. and Manna, C.K. (2011). Identification of dorsal guard hairs of five species of the family Cercopithecidae (Primates: Mammalia). Current Science 100(11):1725-1727.

Teerink, B.J. (1991). Hair of West-European mammals: atlas and identification key. Cambridge University Press, Cambridge, 224 Pp.

Toth, A.M. (2002). Identification of Hungarian Mustelidae and other small carnivores using guard hair analysis. Acta Zoologica Academiae Scientiarum Hungaricae 48(3): 237-250. 